\title{
GOSPODARSKO ENERGIUSKI VIDIK PRI GEOGRAFSKEM PROUČEVANJU
}

\author{
Cene Malovrh*
}

IZVLEČEK

UDK 911.3:330.31

Članek je teoretični prispevek $\mathrm{k}$ problematiki dejavnikov družbene reprodukcije za prostorski razvoj.

\section{ABSTRACT}

UDC $911 \cdot 3: 330,31$

ECONOMIC-ENERGY ASPECT IN GEOGRAPHICAL RESEARCH

The article is an theoretical contribution to the problems of all social-reproduction factors in the spatial development.

Posledice množe $x_{i h}$ se in vedno bolj kompleksnih interakcij v odnosih med družbo in prostorom, v katerem družba obstaja, so jasno izražcne tako v kolixinskem kot v kakovostnem oziru. Ko se vprasujemo po vzrokih povecevanja in zamotavanja te dinamike, pomisimo najprej na to, da se spreminjajo pogoji njenega nastajanja. Treba je torej razjasniti predvsem spremembe zadevnih pogojev.

Osrednji, poglavitni predmet geografskega prouðevanja so pojavi v prostoru, v katerem ljudje živijo, trosijo dobrine in se oskrbujejo z njimi, kjer torej poteka proces družbene reprodukcije. Poznati moramo zakonite znaciinosti tega procesa, in sicer osnovne, ki so vzdržne, in atributivne, ki se vežejo na osnovne in se uvrščajo med pogoje spremenljivosti označne interakcijske dinamike. Upoštevati pa moramo tudi zakonitosti, ki veljajo za sleherni proces, za vse vrste in oblike gibanj.

Družbena reprodukcija je eden izmed mnogih procesov oziroma procesnih sistemov, katerih zakonitosti vladajo $\mathrm{v}$ Svetu in s tem omogoxajo njegov obstanek. Pomensko izenacen $z$ drugimi procesi, se od njih loci predvsem po tem, da se $\mathrm{v}$ razmeroma kratkih obdobjih izpopolnjuje navzlic temu, da se v njegovem poteku ter razvoju kažejo intervali vzpona, stagnacije in nazadovanja. Izpopolnjevanje ter kakovostno nihanje procesa sta posledica izpostavljenosti silam, katerih mediji so zelo raznovrstni in raznorodni pojavi, kakrక̌ne predstavl jajo v prostoru prisotne vrste, oblike ter načini obnasanja snovi, stvari in življenja. Vsi ti mediji so oddajniki in sprejemniki vplivnega uXinkovanja sil, s cimer se tvorijo spleti sil, izraženi kot mox, to je, kot lastnost snovi in enot stvari ter življenja, katero oznacuje sposobnost opravljati delo.

\footnotetext{
* Dr., red.univ.prof., 61000 Ljubljana, Aleševčeva 31, YU.
} 
Sile same po sebi ne opravljajo dela. Šele ko se in v kolikor se razlixne sile povežejo $v$ medsebojnih spletih in pride do nastanka moxi, se zacno delovno uveljavljati. Ne poznamo bistva in nastanka sil, a vemo, da nastopajo in tvorijo splete v prostoru, kar je poudarjeno izraženo zlasti v prostoru, kjer poteka družbeno življenje. Tukaj zaznavamo sile po kategorijah pojavov: neživega sveta, npr. sila razliðnosti elementov, njihove vezljivosti, razlixnosti najmanjših delcev snovi, agregatnega stanja, afinitete, trdnosti, pretvorljivosti snovi, vztrajnosti gibanja, itd.; živega sveta, npr. sile presnavljanja, tvorjenja celice, življenjskega ritma in kroženja, razmnoževanja, dednosti, ohranjanja vrstc, cutenja, itd; cloveka, npr. sile razumnosti, stvarnega in abstraktncga spoznavanja, izražanja misli, nravnosti, tekmovanja, ambicioznosti, nadarjenosti, naklonjenosti, sovražnosti, itd.; družbe npr. sile družbenih odnosov, proizvajalnih odnosov, oblikovanja enot družbene skupnosti, družbene pripadnosti, itd.; prostora, npr. sile soobstojnosti snovi razlið̌nega agregatnega stanja, večrazsežnosti prostora, razmestitvcnih odnosov, itd.; svetovja, npr. sile težnosti in krožnosti gibanja; Casa: sila neobdržljivosti trenutnega stanja.

S spletom sil nastala mox je sposobna delovati $\mathrm{v}$ statixnem in $\mathrm{v}$ dinamixnem izrazu. Zaradi statǐ̌nega delovanja moxi je vsaka snov sestava najmanjక̌ih delcev, ki imajo Łe sami samosvojo notranjo sestavo. Iz snovi nastale oblike stvari in življenja so prav tako sestava delov. Vse raznovistne snovi in razliěne oblike stvari ter življenja so kot sestave izraz statǐnega delovanja moxi, oznacuje jih samosvoj notranji ustroj in disponiranost za tvor jenje ter spreminjanje spletov sil.

Dinamični izraz delovanja moxi pa so gibanja, procesi. Obstajajo procesi v neživi naravi, kakršen je npr. razstavljanje spletov znotraj najmanjకih delcev snovi, procesi $\mathrm{v}$ živi naravi, npr. fotosinteza, procesi v družbenem življenju, npr. programirano izpeljano oskrbovanje z življenjskimi dobrinami, itd.

Moč je potentakem sposcbna hkrati opravljati tako delo sestavnosti, notranjega ustroja in zunanje oblikovitosti snovi ter enot stvari in življenja, kot delo v procesih. Obojni izraz v casovnem razponu potekajocega uresniðevanja moxi je zmogljivost aii energija.

Gibanje, ki ga predstavija družbeno življenje oziroma družbena reprodukcija nastane, poteka in se razvija $\mathrm{v}$ gospodrskem prostoru tako, da se kompleksno, $\mathrm{v}$ odvisnem prepletanju in v ođvisnih razmerjih uveljavljajo vplivne sile ter se uresnixujejo moxi, katerih mediji odnosno nosilci so mnogovrstni čeni ter obnašanje clenov vsake izmed Zemlji lastnih kategcrij pojavov, to jə, pojavov neživega sveta, živega sveta, človeka, družbe, prostora in svetovja. Tako na siroko razvejano odvisno prepletanje si! in delevanje moxi zbuja pozornost v vex ozirih. Najprej prepričje, da je vioga prostora $\mathrm{v}$ družbenem življenju neprimerno pomembnejš, kot se prikazuje v primerih, ko to 
vlogo obravnavamo enostransko, najpogosteje glede na obstajanje stvari v razsežnosti prostora. Še važnejšc pa je, da daje prav spletanje raznorodnih sil in ustrezajoce delovanje moxi povod in spodbudo iskanju odgovora na vprašanje, zakaj energija procesa družbene reprodukcije in njenih oddelkov ni v celoti, ampak je le delno obvladovana, in dalje na vprasanje, kako preprexiti ali vsaj omiliti nezaželjeno vplivno uxinkovanje sil, posredovanih s pojavi, ki spontano vznikajo v potekanju reprodukcijskega procesa?

Pristop k razjasnjevanju navedenih vprašanj dolocujejo zakonitosti, ki veljajo za potek slehernega procesa. Med temi zakonitostmi so poglavitne naslednje:

- Dispozicija za vplivno uđinkovanje z mediji posredovanih sil je zdržna, casovno neomejena, medtem ko je uresnixevanje moxi, $s$ katero trenutno razpolagajo $v$ nekem segmentu ali fazi procesa sodelujoci faktorji, casovno omejena, delujoča energija slabi in je slabitev preprečevana le s sprotnim obnavljanjem moxi faktorjev.

- V vsakem procesu se uveljavlja vplivno uđinkovanje sil, katerih mediji so: a) enote vrst ter oblik stvari in življenja, tvore $x_{i h}$ kategorijo velikih biti (makroentitete, kot so zrak, voda, kamnine, človek, živali, rastline, naravni in ustvar jeni predmeti, itc.), in b)

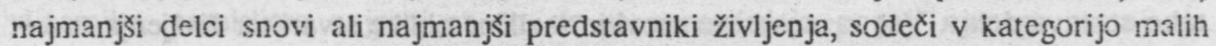
biti (mikroentitete, kot so molekula, atom, proton, elektron, ion, itd., in ce!ica, kromosom, bakterija, virus, itd.). Zdržno vplivno uxinkovanje $\mathrm{z}$ obema kategorijama biti posredovanih sil je najtesnc je odvisno povezano in je zato za potek in razvoj gibanja pomemono razmerje intenzitete enega in drugega uxinkovanja.

- V vsakem gibanju nastopajo vzbujalni in odzivni procesni segmenti. Prvi nastane jo s spleti neposrcảno uveljavljajocih se sil, v gibanju deluje neposredna energija. Drugi nastanejo zaradi odzivnega aktiviranja sil, ki zacno ucinkovati v spletu s silami, uveljavljajoðimi se v žc potekajočem procesu, v gibanju deluje encrgija posreçno. Čim pride do sledeče spremembe spleta sil, dobi odzivni procesni segment znąaj vzbujalnega segmenta, gibanje se nadaljuje bodisi $z$ drugaeno stopnjo intenzivnosti bodisi $v$ odklonjeni smeri. Pestrejse ko je menjavanje spletov sil, posredovanih s kategorijama velikih in malih pojavnih oblik, pogostejse ko je izmenično delovanje neposredne in posredne energije, vec je povodov in pobud za spremembe v potekanju procesa, živahnejşi je razvoj.

Za potek in razvoj reprodukcije po enotah družbene skupnosti je izhodiß̌no pomembna družbena delitev dela, pojav, ki ga je porodilo že zgodnje spoznanje prednosti specializacijskega izkorišcanja zmogljivosti pri ustvarjanju dobrin udeleženih faktorjev: faktcrjem lastna energija mora biti samo na ta način z znatnim deležem uresnična $v$ enoti listvarjene dobrine. Ker je na vsakokratni doseženi ravni znanja 
uporabna zmogljivost dobrine najpopolneje uresniŁena, je prihranjevana energija faktorjev tudi v procesih bodisi proizvajalne bodisi potrošne rabe dobrine. Mimo tega se prihranjuje se energija specializantsko neizurjenim interesentom za dobrino, ki bi sicer porabili za njeno pridobitev vec casa in bi s svojim naxinom dela ne mogli zagotoviti zahtevane kakovosti. Z družbeno delitvijo dela uravnani specializacijski pristop $\mathrm{k}$ ustvarjanju dobrin omogoca torej predvsem prihranjevanje energije faktorjev.

Vzporedno s koristmi, katere prinasa družbena delitev dela, narašca nezaželjena vplivnost sile, ki jo posreduje s to delitvijo okrepljena lastnost redkosti dobrin na kraju in $\mathrm{v}$ casu njihove rabe. Priskrbovanje mora neizogibno nujno poteci $\mathrm{z}$ menjavanjem na trgu dobrin, seveda tako, da je tekoče neprekinjeno, s čmer se zmanjša ali celo iznixi vplivno uxinkovanje lastnosti redkosti. Med pogoji izvajanja tržnega naxina neprekinjenega oskrbovanja $z$ dobrinami izstopata zlasti naslednja dva. Prvi je ta, da menjava dobrin razlixnih vrst zahteva enotno merilo; le-tega dolocujejo uporabna zmogljivost enote posamezne vrste dobrine, možnost prihranjevanja energije faktorjev, udeleženih pri ustvarjanju in pri rabi dobrine ter stopnja redkosti dobrine na kraju in v casu rabe; za ponazorilo tega merila so ljudje izbrali posebno vrsto dobrine, to je, denar. Drugi pogoj je osnovanje poslovne podlage, s katero mora razpolagati vsak ponudnik dobrin na trgu, in katero predstavlja obstoj zalog predmetnih in denarnih poslovnih sredstev, ki se ne porabijo naenkrat $\mathrm{v}$ enem samem procesu, ampak postopno $\mathrm{v}$ vec, tekom nekega časovnega razpona ponavljajočih se ustvarjalnih procesil;; ker se v teku casovnega razpona gospodarski osebki oskrbujejo s poslovnimi sredstvi iz trenutno in lokacijsko zanje cenovno najugodnejsih izvoriš in se $\mathrm{v}$ istem razdobju bolj ali manj spreminja tudi tržni položaj sredstev, je mogoč s prcracunljivim posiovnim ravnanjem zagotavljati prescžni dohodek odnosno dobið̌ek.

Pridobivan je dobicka, to je, cenovnega pribitka na strošk ustvarjanja na trgu prodane dobrine, je prvobitno utemeljeno ter družbeno priznano vsled prednosti, ki so izkazane s prihranjevanjem energije in s prepreðevanjem nezaželjenega vpliva lastnosti redkosti dobrine na kraju ter v casu njene rabe. Dobixek kot dohodek iz nedela vzpodbuja vznikanje konkureněne ponudbe na trgu dobrin. Nenchna prisotnost le-te povzroxi slabitev prvobitne utemeljenosti pridobivanja dobicka, ojačje pa pomen poti $\mathrm{k}$ istemu cilju, katero predstavlja preracunljivo ravnanje s sredstvi poslovne podlage podjetja. Dobixek postane tako prvenstveni cilj gospodarjenja, kar bolj ali manj zastira pravi namen te dejavnosti in še zlasti dalekosežno pomembnost specializacijskega izvajanja ustvarjalnega dela.

Specializacijski način ustvarjanja dobrin pride ponovno bolj do veljave in izraza potem, ko se pod vplivom konkurence $\mathrm{v}$ ustvarjaine delavnosti vkljuci industrijsko sredstvo dela, katerega definiramo kot dolocene, preko strojne priprave programirano vzpostavljene, intenzivirane in za ustvarjalno deio izkorišcene naravne energijske 
procese. S pomocjo tega visoko storilnega sredstva in skupaj s samosvojo organiziranostjo industrijskega naxina dela, se poveča izdatnost preskrbovanja $\mathrm{z}$ dobrinami, $\mathrm{s}$ Cimer pa postane zanesljivejక̌e prepređevanje negativnega uCinka lastnosti redkosti dobrin na kraju rabe, kar neizogibno povzroci zaostrovanje konkurenð̌ne borbe na trgu dobrin. Spričo takšnih razmer izstopi ena izmed poglavitnih zakonitosti, ki vladajo $\mathrm{v}$ osnovi, $\mathrm{z}$ delitvijo dela zasnovanega procesa družbene reprodukcije, in sicer: Pri ustvarjanju enote neke dobrine in pri njeni bodisi ustvarjalni ali potrosni rabi, je povsem izenačena važnost uresnicevanja energije vseh kategorij sodelujocih faktorjev: a) clovekove zmogljivosti spoznavanja, znanja, ravnanja in fizičnega delovanja, b) zmogljivosti sredstev dela $\mathbf{v}$ vseh nacinih njihovega uxinkovanja in c) odzivne, vsakemu predmetu dela lastne, njemu inherentne, zmogljivosti.

Z zaostritvijo ponudbene konkurence povečano tveganje pri zagotavljanju normalne stopnje dobicka, prisiljuje dovolj stremuske gospodarske osebke, da de! akumuliranega kapitala porabijo za naložbe $\mathrm{v}$ raziskovanja potencialne izkoristljivosti snovi ter stvari, ki so predmeti dela, dalje v pripravljanje programov ustvarjanja, oprtih na dognanja raziskav, in $v$ uresnix̌cvanje teh programov. Velika storilna učinkovitost $z$ industrializacijo vpeljanih sredstev, se posebno energetske komponente $\mathrm{v}$ industriji rabljenih sredstev, omogođa raziskovanje in spoznavanje obnašanja sil ter moci, s kakršnimi razpolagajo najmanjక̌i delci posameznih vrst snovi. V kolikor je tako obnasanje obvladljivo in obvladovano, se odpira možnost, da po določenem programu in s pomoxjo storilne uxinkovitosti industrijskih sredstev dela izvedeno obdelovanje ter predelovanje snovi, le-tej podeli nove energijske lastnosti ali predrugacen nacin obnašanja sil ter moð̌i. Cilj takšnih prizadevanj je bodisi dobivanje zvrsti ali novih vrst dobrin ₹ namenom, da se obnavlja in vzdržuje tržno prednostna, za ponudrika ugodna, lastnost redkosti, bodisi izpopolnjevanje obstojece teinologijo in organiziranja ustvar jalne delavnosti $\mathrm{z}$ namenom znižanja lastne in tržne cenc po enoti dobrine. $\mathrm{V}$ prvem primeru gre za tip diverzifikacijske inovacije, $v$ drugem za tip racionalizacijske inovacije. Ta dva tipa inovacij praviloma nista izbirna, ker ju narekuje odnos do stopnje gospodarskega tveganja. Izkazalo se je namrex, da daje z rastocim zanimanjem za potrošne novitete usmerjevani dohodkovni interes ponudnikov prednost ustvarjanju zvrsti in novih vrst dobrin. Vloga in pomen racionalizacijske, prihranjevanju encrgije faktorjev namenjene ustvarjalnosti relativno zaostaja.

Intenzivirano specializacijski način izkoriscanja predmetom dela lastnih encrgijskih lastnosti se izrazi łe s tem, da se v dinamiki celotne družbene reprodukcije pospeši tudi ritem zbujalnih in odzivnih procesnih segmentov. Za naglo izmenjavanje teh segmentov je odlocilna zelo povdarjena vloga posredne, $z$ odzivanjem sil najmanjsi dcicev snovi aktivirane, moxi. Intenziviranje potckanja mnogih procesov ustvarjanja in trošenja dobrin na rovaš naglega prcobražanja spletov sil najmanjłsih deicev snovi pa povzroca, da se neobvladane sile, prisotne v neizkorišceni odpadni gmoti snovi in stvari, s prav takšno intenzivnostjo neregulirano, prosto, uveljavljajo v spletih s sila- 
mi, katerih mediji so razlicnc sestavine okolja. Posledica je rušenje naravnega ravnotežja energijskega krogotoka v ožjem okolju, a tudi v siršem obmox ju.

Ker je motiv in cilj konkurenæne ponudbe identixen s tistim prvotne ponudbe dobrin, to je z zagotavljanjem stopnje presežnega dohodka, ostaja inovacijska dejavnost takorekox neprekinjeno prisotna s svojimi pozitivnimi in negativnimi rezultati. Negativne posledice inovacij bi bilo mogoce omejiti le $\mathrm{v}$ primeru, ako bi se $\mathrm{v}$ smotru marketinßko naravnane poslovne politike s poudarkom izrazila zahteva, da se pot na tržišce utre prvenstveno le tistim novim dobrinam, katerih ustvarjanje in raba omogočata, da se prihranjuje energija in so prepre`evani §kodljivi učinki v ckolju. Toda z naglo izvedbo tovrstnega preokreta $v$ tržni odnosno vobce ustvarjalni dejavnosti, se ne kaže racunati; vsaj ne toliko casa, dokler ne bi prisila kvarov in కkod v življenjskem okolju dosegla stopnje, ko bi unixevanje pojavov življenja in pojavov blaginje dobilo množični obseg. Niso pa zanemarljiva znamenja, ki pričjo o težnjah in volji, da pride do naznacenega preokreta postopoma in na stvarno izvedljivi nacin.

V gospodarski politiki sledimo pobudam in že poskuson izvajanja zamisli tako imenovane ekonomske demokracije. Po tej zamisli so vsi udeleženci v posamezni ustvarjalni enoti ali podjetju udeležcni tudi pri lastnistvu, posiovnem odloxanju in delitvi dobicka. Tako razširjena organizacijska osnova za obravnavanje prvin poslovne podlage podjetja in za $n$ jih funkcioniranje, ima poleg glavnega namena se vzporedni smoter: konkretno materialno spodbujani naj se vsi udeleženci zadolžujejo s kar se da vsestransko kritix̌nim presojanjeni vprałanj, ki se tið̌ejo pogojev vzdrževanja normalnih razmer in potekanja procesov $\mathrm{v}$ obeh vsebinskih razdelkih družbene reprodukcije, to je, na torišcu bivanja in trošenja dobrin ter na torišcu ustvarjanja in priskrbovanja dobrin. Izrazne poteze gospodarsko energijskega naboja družbene reprodukcije dovolj jasno opozarjajo, da je na sedanji ravni industrializacije že treba ocenjevati znaten del prizadevanj za omiljenje poslovnega tveganja samo v luci tveganosti prihodnjega razvojnega napređovanja celotnega življenja. Postavlja se zahteva, $v$ smislu katere se mora gospodarsko politicno trasiranje in poslovno ukrepanje presojati $\mathrm{z}$ ekonomskega in ckoloskega vidika hkrati.

Mnoge znacilnosti naglih razvojnih sprememb družbene reprodukcije sedanjega casa opozarjajo, da bi moral dobiti pri prouXevanju tega procesa, vsled njegove imanentne prostorske obeleženosti, vodilni pomen energijski, točncje gospodarsko energijski vidik. So razlogi, ki govorijo, da je geografija prva poklicana utirati tak pristop $\mathrm{k}$ proučevanju. Ta disciplina ima sijajne možnosti, da zasnuje in utrjuje metodologijo interdisciplinarnega raziskovanja družbenega življenja s sredsivi, ki služijo spoznavni analizi in spoznavni sintezi. In upoštevati velja, da geografija je in bo ostala solski uxni predmet; lahko si predstavljamo, koliko bi s posredovanjem spoznanj prispevala k vzgoji in osvešcanju pokolenja, katerega clani bodo ‘ez nekaj let vsak zase za nekaj desetletij zadolženi s soodlox̌anjem o tem, po kakšni stopnji racionalnosti bo potekal in se razvijal zapleteni proces družbenega življenja. 


\section{ECONOMIC-ENERGY ASPECT IN THE GEOGRAPHICAL RESEARCH}

The process of social reproduction, that is, consuming and producing of goods necessary for living, takes part and develops in geographical environment and binds dependably the influence of forces which media are the categories of phenomena belonging to the whole Earth: the phenomena of lifeless world, living world, man, socicty, place, time and universe. There is a power created by the link of different forces, which in the course of time and in dynamic expression proves itself in processes as energy.

The studies of social reproduction too, should include energy aspect, more exactly economic-cnergy aspect which is determined by the rules characteristic for every process. Two things among them are emphasized:

- The influence of forces is being present in each process. The medias of forces are: a) the units of species and forms of objects and life creating the category of great beings (macroentities: air, water, soil, man, animals, plants, natural and produced objects, et.) and b) the smailest parts of the substance, or the smallest representatives of life, belonging to the cathegory of small beings (microentities: a molecule, an atom, a proton, an electron, an ion etc. and the cell, chromosome, bacterium, virus, etc.) Permanent influential effect, together with both categories of forces, is most closely and dependably connected.

- There are initiative and reacting segments being present in every process. The first ones are created by the links of directly aserted forces. There is direct energy taking part in the process. The second ones are creaied because of the reacting activity of forces, which start to influence together with forces being created in the course of the present process. There is indirect energy being present in the movement. As soon as the following change of the link of forces occurs, the reacting segment in the process gets the character of initiative segment; the movement is going on with different degree of intensity of in declined direction. The development of the process is more vivid when the aiternating influence of direct and indirect energy is more frequent.

Supplying with goods, being carried out by the ruie of the social division of labour, cnables the saving of energy in the process of cooperative factors and at the same time it makes undesirabie influential effect of the rarity of goods stronger in place and time of their use. Both things justify the fact, that offerers of goods in the market add profit to their own expenses. The profit stimulates competition, which lessens the negative character of the rarity of goods, and for that reason the compe- 
titive fight becomes sharper. Ambitious businessmen start to invest part of their capital into researches and production of new kinds of useful materiais intended for creating up to now unknown goods. High efficiency of industrial means of work is of great importance. By the help of industrial means of work it is possible to change joints of forces of the smallest parts of the matter, so that alternation of initiative and reacting segments in the process is very accelerated. For that reason undefeated forces, which are present in the unexploitable, wasteful mass of matter, in the same intensive way, fast, unregularely and freely prove themselves in the links together with forces which media are different components of the environment; the consequence of this is destruction of energy circle in the environment.

Thus inovations at the present level of industriaisation have negative consequences, too. Because of this, the idea that all the employees within the firm should share ownership, management and profit, is of great importance (economic democracy). In this way everybody would be directly, materially stimulated, and everybody would in his own interest directly determine the conditions; which in the sphere of living and spending of goods and in the sphere of producing goods enable savings of energy and the prevention of threatening of life.

Geographic science is because of more and more complex interactions in the relations between society and living place, more and more called to introduce economic-energy aspect in its studies, especially because it has good conditions for introducing interdisciplinary approach, which enables the researches of social reproduction. As such, geographic science as school subject with its discoveries can contribute a lot to education and awareness of young people, who will have to decide at their working places about the degree of rationality within which complicated process of social life will developed. 